\title{
PENERAPAN SISTEM INFORMASI PENJUALAN DAN INVENTORI HANDPHONE SERTA AKSESORISNYA MENGGUNAKAN ENTERPRISE RESOURCE PLANNING (ERP) (Studi Kasus: Toko Nahda Cell)
}

\author{
Aries Munandar AM 1, Ricky Akbar 2*), Efrizon 3 \\ 1,2) Jurusan Sistem Informasi Fakultas Teknologi Informasi Universitas Andalas \\ 3) Pasar Bawan Kec. Ampek Nagari \\ (coresponding author) rickyakbar1984@gmail.com *), ariesmunandar22@gmail.com
}

\begin{abstract}
Currently, the implementation of business processes in Nahda Cell Mobile Shop is not using computerized. All transactions are still applying a noted invoice. Sales Reports and Stock items are still using a book to record all transacttions. It will have consequences to services and bookkeeping's problem at this shop. It need a compact solution to solved this problem. One of them is by implementing information systems using Enterprise Resource Planning (ERP). ERP applications can be customized and it also an open source applications. Implementation of ERP in Nahda Cell shop is started with a preliminary study, further study of literature is used to find basic concepdt and previous research about the implementation of the same systems, identification of current business process inventory and sales of goods and proposed a computerized syste, which is described using Business Process Model Notation (BPMN), and the proposed system is modelled using use case diagram. The next step is to analyze selection process of OSS ERP applications, application deployment and testing of applications. The results of this research indicate that the selected of OSS ERP applications can provide solutions to the problems in Nahda Cell Mobile shop.
\end{abstract}

Keyword: Information System, ERP, Sales, Inventory, BPMN

Intisari - Saat ini proses bisnis yang berjalan di Toko Handphone Nahda Cell belum terkomputerisasi. Semua transaksi masih menggunakan blangko faktur. Laporan Penjualan dan Stok barang masih menggunakan pencatatan secara manual dibuku. Hal ini tentu akan berakibat terhadap pelayanan dan pembukuan yang tidak baik pada toko tersebut. Untuk itu diperlukan solusi agar permasalahan itu dapat diatasi. Salah satunya dengan penerapan sistem informasi menggunakan aplikasi Enterprise Resource Planning (ERP). Aplikasi ERP ini dapat dirancang sendiri dan dapat juga menggunakan aplikasi yang open source. Penerapan ERP pada Toko Nahda Cell menggunakan ERP yang bersifat Open Source Software (OSS). Tahapan yang dilakukan dalam penerapannya dimulai dengan studi pendahuluan, selanjutnya studi literatur digunakan untuk mencari landasan teori dan penelitian terdahulu tentang penerapan sistem ERP, mengidentifikasi proses bisnis inventory dan penjualan barang yang sedang berjalan kemudian membuatkan usulan sistem secara terkomputerisasi, yang digambarkan dengan menggunakan Business Process Model Notation (BPMN), serta penggambaran model kerja sistem yang akan diterapkan menggunakan use case diagram. Kemudian tahapan selanjutnya adalah melakukan analisis pemilihan Aplikasi ERP OSS, penerapan aplikasi dan pengujian aplikasi. Hasil penelitian ini menunjukkan bahwa aplikasi ERP OSS yang dipilih dapat memberikan solusi terhadap permasalahan yang dihadapi toko Handphone Nahda Cell.

Kata Kunci: Sistem Informasi, ERP, Penjualan, Inventori, BPMN.

\section{PENDAHULUAN}

Pada saat sekarang ini persaingan antar pelaku usaha semakin tinggi dan menuntut para pelaku bisnis untuk terus mengasah kreatifitasnya dalam menciptakan inovasi baru, menghasilkan produk yang berkualitas serta strategi penjualan yang baik hal ini perlu dilakukan untuk menarik minat para konsumen dan untuk menghasilkan laba yang sebesar-besarnya. Menurut Suprijanto (2006), “Kebiasaan yang terjadi sekarang dalam tiap perusahaan adalah dengan meningkatkan jumlah konsumennya dan melakukan pelayanan yang cepat serta biaya yang murah dibandingkan dengan kompetitornya. Salah satu cara untuk mewujudkan kesuksesan tersebut dapat dilakukan dengan mengintegrasikan sistem informasi, peningkatan efisiensi dari sistem informasi untuk menghasilkan manajemen yang lebih efisien dalam proses bisnis. Ketika perusahaan menjadi lebih efisien akan meningkatkan daya saingnya di pasar bisnis." 
Salah satu solusi untuk mewujudkan hal ini adalah dengan penerapan Enterprise Resource Planning (ERP). Penerapan dari sistem ERP pada perusahaan diharapkan mampu meningkatkan produktivitas dan kualitas dalam pelayanan konsumen, keunggulan produk dan pengetahuan manajemen, sampai akhirnya penerapan ERP diharapkan dapat meningkatkan kinerja dan nilai pasar perusahaan melalui peningkatan efektifitas dan efisiensi operasi perusahaan [1].

Toko Nahda Cell ini merupakan toko yang menjual berbagai macam merek handphone seperti Nokia, Samsung, BlackBerry, ICherry dan lain sebagainya. Selain itu Toko Nahda Cell juga menjual berbagai macam aksesories handphone seperti Baterai Handpone, Headset, Power Bank, Charge, Kartu Memori dan lainnya. Toko Nahda Cell merupakan salah satu usaha menengah yang dikelola oleh Efrizon beralamat di jalan lintas padang-pasaman, terletak di pasar bawan kecamatan Ampek Nagari. Toko Nahda Cell juga bekerja sama dengan distributor pembayaran listrik, pembayaran kredit motor, pembelian tiket pesawat, pulsa listrik dan juga tempat pembelian tiket travel.

Dari hasil wawancara yang dilakukan kepada Efrizon (2016) sebagai pemilik usaha yang mengatakan bahwa Toko Nahda Cell merupakan salah satu toko handphone yang ramai dikunjungi oleh pelanggan. Setiap harinya ada sekitar lebih kurang 35 orang berkunjung di toko tersebut. Ada yang membeli barang, service, atau hanya sekedar menanyakan keluaran Handphone terbaru. Tetapi sistem yang digunakan dalam proses bisnisnya masih dilakukan secara manual. Ketika pelanggan datang berbelanja, nantinya akan dilayani oleh seorang staf penjualan. Pelanggan akan melihat barang yang ingin dibeli dan memintanya kepada staf penjualan. Staf penjualan akan mencarikan barang belanjaan yang diinginkan pelanggan. Pelanggan membayar belanjaan kepada dan staff penjualan menerima uang pembayaran dan menyimpannya. Begitu dilakukan seterusnya tanpa ada pencatatan penjualan untuk toko dan bukti pembelian yang diberikan pelanggan.

Selain dari tidak adanya pencatatan penjualan dan bukti pembelian untuk pelanggan, untuk persediaan barang ditoko pun juga susah diketaui. Hal ini disebabkan karena pencatatan persediaan pun tidak jelas. Persediaan yang dimiliki oleh toko hanya dilihat dari banyaknya stok pada tempat penyimpanan secara manual. Jika stok barang sudah sedikit atau habis, maka pemilik baru akan pergi ke pemasok untuk membeli barang dagang, dan membawanya pulang. Sampai di toko baru disimpan berdasarkan tempat penyimpanan yang telah disesuaikan sebelumnya. Ini bisa saja berdampak buruk bagi usaha Toko Nahda Cell karena tidak dapat mengetahui apa yang sedang terjadi dalam usahanya, mereka tidak tahu apakah usaha yang dilakukannya ini dalam masa laba atau dalam masa merugi.

Melihat dari masalah yang ada pada usaha Toko Nahda Cell, maka diperlukanlah suatu sistem informasi yang dapat membantu usaha ini dalam menjalankan bisnisnya agar menjadi lebih baik lagi, salah satunya dengan menggunakan Aplikasi ERP. Maka dari itu penulis tertarik melakukan penelitian ini dengan judul Penerapan Sistem Informasi Penjualan dan Inventori Handphone serta Aksesorisnya menggunakan Enterprise Resource Planning (ERP) (Studi Kasus : Toko Nahda Cell)

\section{A. Sistem Informasi}

\section{LANDASAN TEORI}

Menurut Erwan Arbie (2000), Sistem informasi adalah sistem di dalam suatu organisasi yang mempertemukan kebutuhan pengolahan transaksi harian, membantu dan mendukung kegiatan operasi, bersifat manajerial dari suatu organisasi dan membantu mempermudah penyediaan laporan yang diperlukan [2]. Sementara itu Menurut Tafri D. Muhyuzir (2001) Sistem Informasi adalah data yang dikumpulkan, dikelompokkan dan diolah sedemikian rupa sehingga menjadi sebuah satu kesatuan informasi yang saling terkait dan saling mendukung sehingga menjadi suatu informasi yang berharga bagi yang menerimanya [3].

\section{B. Enterprise Resource Planning (ERP).}

Enterprise Resource Planning (ERP) merupakan paket sistem informasi yang dapat dikonfigurasi, yang mengintegrasikan informasi dan proses yang berbasis informasi di dalam, dan melintas area fungsional dalam sebuah organisasi [4]. Satu basis data, satu aplikasi, dan satu kesatuan antarmuka di seluruh enterprise [5]. Software ERP mendukung proses bisnis yang efisien dengan mengintegrasikan aktivitas bisnis, termasuk penjualan, pemasaran, produksi, logistik, akuntansi dan sumber daya manusia [6]. Konsep ERP dapat dijalankan dengan baik, jika didukung oleh seperangkat aplikasi dan infrastruktur komputer baik software dan hardware sehingga pengolahan data dan informasi dapat dilakukan dengan mudah dan terintegrasi. Oleh karena itu, hampir tidak mungkin mewujudkan konsep ERP tanpa adanya dukungan sistem berbasis computer. Konsep ERP ini dapat dilihat pada gambar 1. 


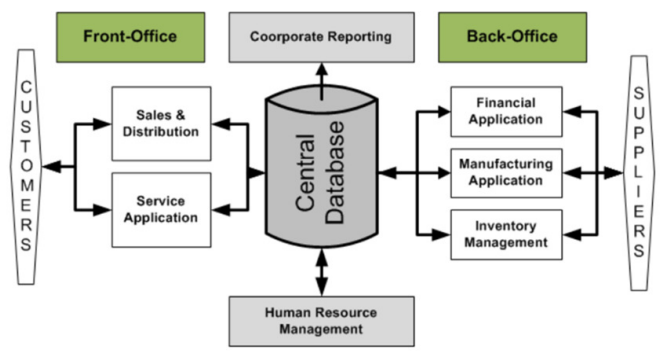

Gambar 1 Konsep Dasar ERP [12]

\section{Penjualan}

Penjualan merupakan kegiatan yang dilakukan oleh penjual dalam menjual barang atau jasa dengan harapan akan memperoleh laba dari adanya transaksi-transaksi tersebut dan penjualan dapat diartikan sebagai pengalihan atau pemindahan hak kepemilikan atas barang atau jasa dari pihak penjual ke pembeli [7]. Sedangkan penjualan menurut Winardi dalam bukunya Pengantar Manajemen Penjualan (Sales Management) (1999:176), menyatakan bahwa Penjualan adalah hasil yang dicapai sebagai imbalan jasa-jasa yang diselenggarakan yang dilakukannya perniagaan transaksi dunia usaha. Sementara itu menurut IAI dalam SAK No 23 (2009), Penjualan barang meliputi barang yang diproduksi perusahaan untuk dijual dan barang yang dibeli untuk dijual kembali seperti barang dagang yang dibeli pengecer atau lainnya. [8]

\section{Persediaan}

Persediaan adalah aset lancar dalam bentuk barang atau perlengkapan yang dimaksudkan untuk mendukung kegiatan operasional pemerintah daerah, dan barang-barang yang dimaksudkan untuk dijual dan/atau diserahkan dalam rangka pelayanan kepada masyarakat (http://keuda.kemendagri.go.id).

Menurut (standar akuntansi keuangan, 1999) pengertian persediaan adalah aktiva:

- $\quad$ yang tersedia untuk dijual dalam kegiatan usaha normal;

- dalam proses produksi dan atau dalam perjalanan;

- dalam bentuk bagan atau perlengkapan (supplies) untuk digunakan dalam proses produksi atau pemberian jasa

Menurut Sipper et al.(1997, p206) definisi Persediaan adalah sejumlah komoditas atau barang dagangan dalam hal pengontrolan dari sebuah perusahaan, disimpan selama beberapa waktu untuk memenuhi permintaan yang akan datang [9].

\section{ANALISIS PROSES BISNIS PERUSAHAAN}

A. Proses Penjualan Handphone dan aksesoriesnya yang Sedang Berjalan

Alur dari penjualan handphone dan aksesoriesnya yang sedang berjalan, antara lain:

1. Pelanggan datang untuk membeli handphone atau aksesoriesnya

2. Pelanggan akan memilih barang yang akan di belinya tadi

3. Kemudian pembeli membayar barang dagangan yang di belinya tadi ke si penjulan.

4. Barang yang terjual tadi dicatat di buku penjualan harian

Gambar alur prosesnya dibuat menggunakan Bussiness Process Model Notarion (BPMN), yang dapat dilihat pada gambar 2. 


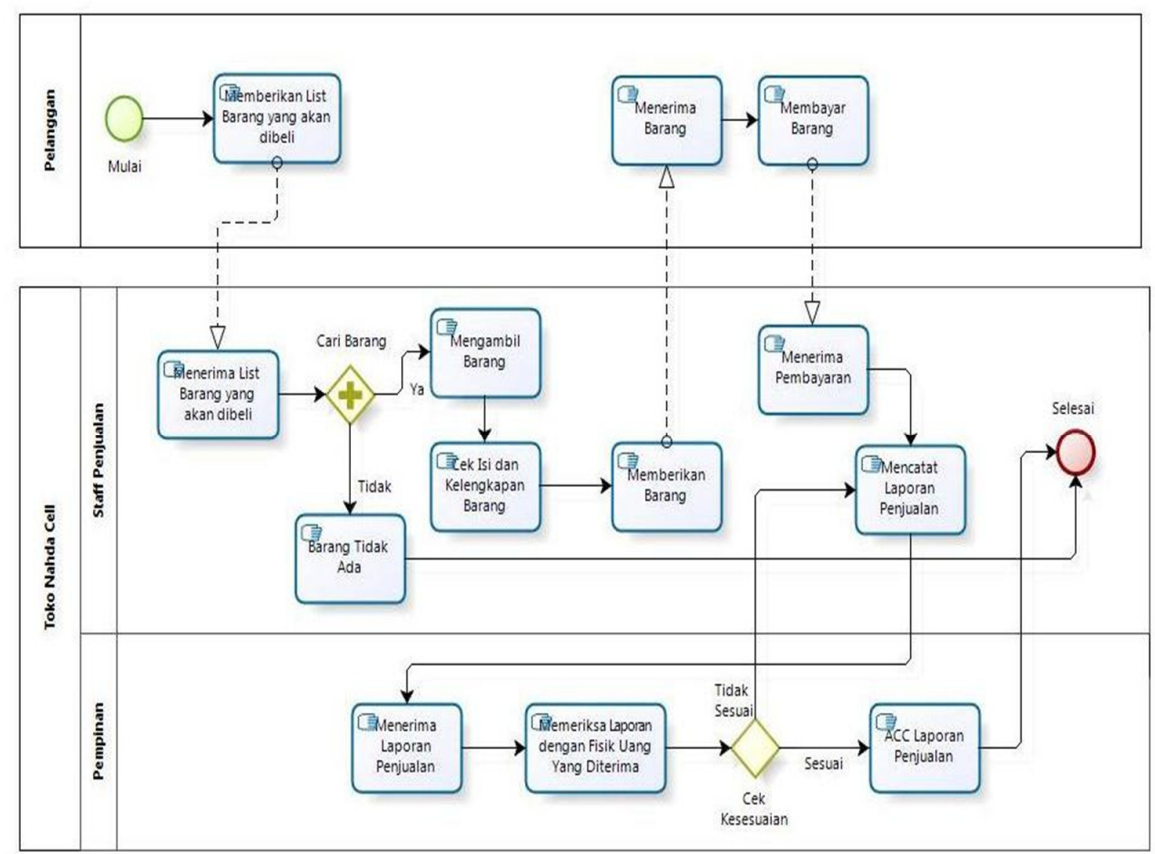

Gambar 2 BPMN Proses Penjualan yang Sedang Berjalan

B. Proses Penjualan Handphone dan aksesoriesnya yang Diusulkan

Alur dari Proses Penjualan Handphone dan aksesoriesnya yang diusulkan, antara lain:

1. Pelanggan datang ke Toko Nahda Cell untuk membeli barang yang dibutuhkan pelanggan

2. Barang yang telah dipesan pelanggan dan data pelanggan dimasukan datanya kedalam komputer

3. Setelah data terpenuhi, system dapat mencetak barang yang di beli.

4. Secara otomatis stok yang ada akan berkurang.

5. Kemudian pelanggan membayar barang belanjaan dan menerimanya.

Dapat dilihat perbedaannya dari yang sedang berjalan, bahwa yang diusulkan sudah terkomputerisasi dan menggunakan database sebagai media penyimpanannya. Barang yang dijual pun tidak perlu dilihat manual, karena sudah dapat dicek melalui stok yang ada dikomputer, sehingga dapat mempercepat proses penjualan. Alur proses penjualan yang diusulkan ini dapat dilihat pada gambar 3

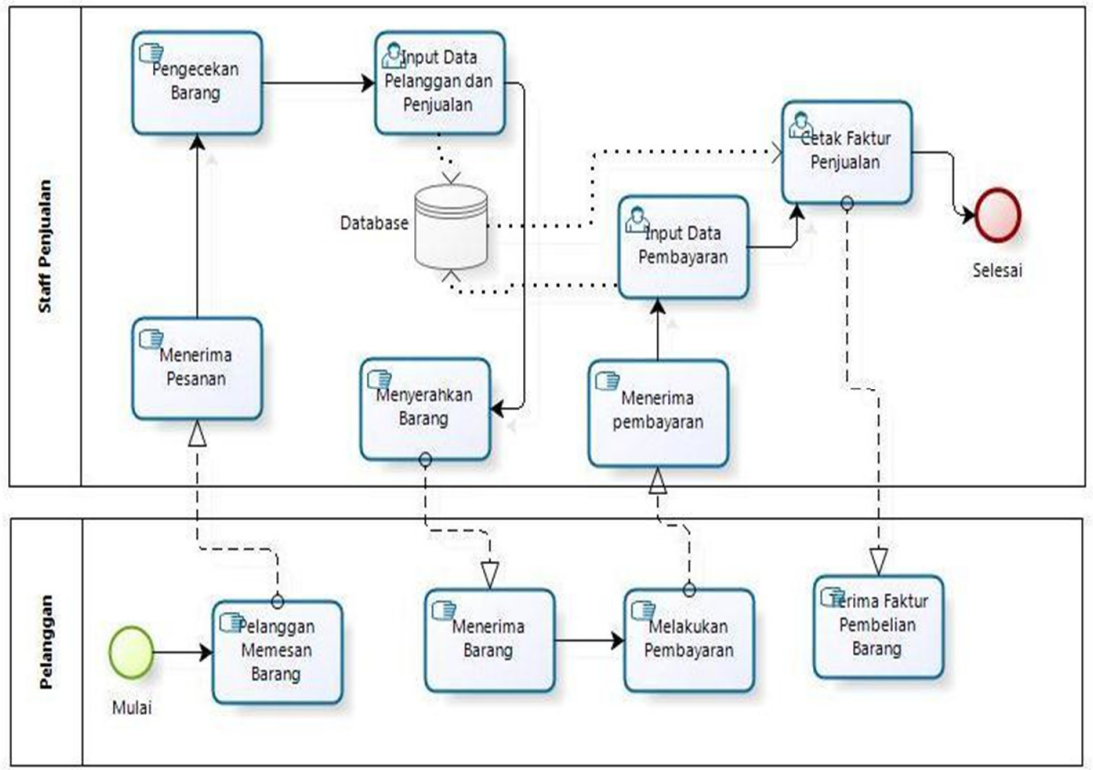

Gambar 3 Proses Penjualan Handphone dan aksesoriesnya yang diusulkan 
C. Proses Inventory Handphone dan Aksesoriesnya yang sedang berjalan

Alur Proses Inventory handphone dan aksesorisnya yang sedang berjalan adalah sebagai berikut :

1. Pihak gudang membuat list barang yang akan dibeli

2. Bagian Penjualan menerima list barang yang akan dibeli dari gudang dan melakukan pemesanan barang ke Pemasok.

3. Bagian penjualan nanti akan menerima barang yang sudah dibeli dari pemasok dan melakukan pengecekan terhadap barang yang sudah dibeli.

4. Jika barangnya sesuai maka dilkukan pembayaran, tapi jika barang tidak sesuai maka akan dikembalikan ke Pemasok.

5. Setelah melakukan pembayaran, bagian penjualan akan menerima bukti dari pemasok, kemudian barang dikirim ke bagian gudang dan dilakukan update stok barang.

Gambar alur proses inventori ini dibuat menggunakan BPMN seperti yang terlihat pada gambar 4 .

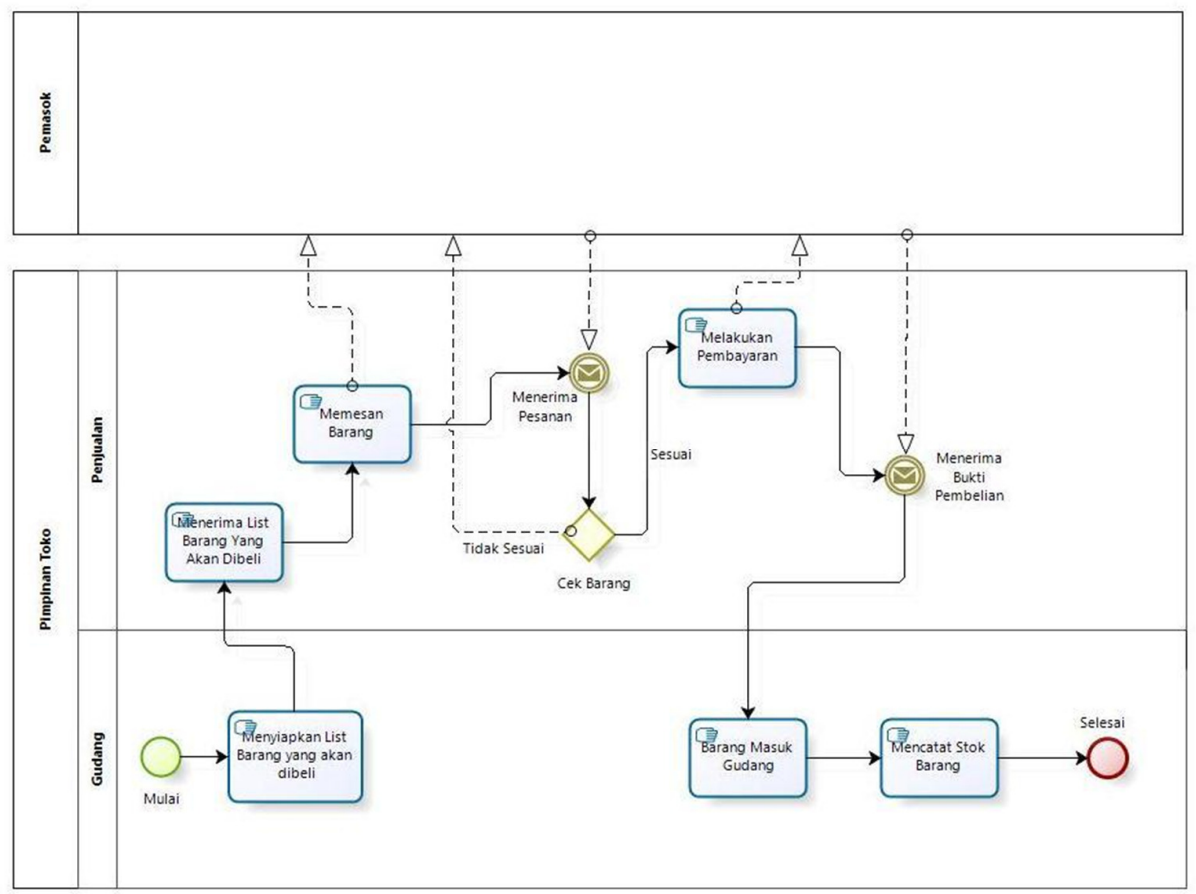

Gambar 4 Proses Inventori Handphone dan aksesoriesnya yang sedang berjalan

D. Proses Inventory Handphone dan aksesoriesnya yang Diusulkan

Alur Proses Inventory handphone dan aksesorisnya yang sedang berjalan adalah sebagai berikut:

1. Bagian penjualan langsung melakukan pengecekan terhadap stok barang yang ada di database dan melakukan pembelian ke Pemasok.

2. Bagian penjualan menerima bukti pembayaran dan melakukan pembayaran sesuai dengan nota dari pemasok.

3. Bagian penjualan melakukan input data barang masuk dan mencetak laporan stok barang

4. Laporan stok barang diberikan ke bagian gudang untuk dilakukan pengecekan barang digudang.

5. Bagian gudang melakukan penyusunan stok barang dan proses selesai.

Dari proses yang diusulkan terdapat perbedaan proses bisnis, yaitu sudah memilii aplikasi yang terintegrasi yang tersimpan dalam satu database. Sehingga untuk pengecekan barang di gudang tidak perlu dilakukan secara manual lagi, namun bisa dicek secara langsung pada aplikasi. Dan laporan terhadap stok barang masuk bisa langsung dicetak. Proses bisnis inventori ini dapat dilihat pada gambar 5. 


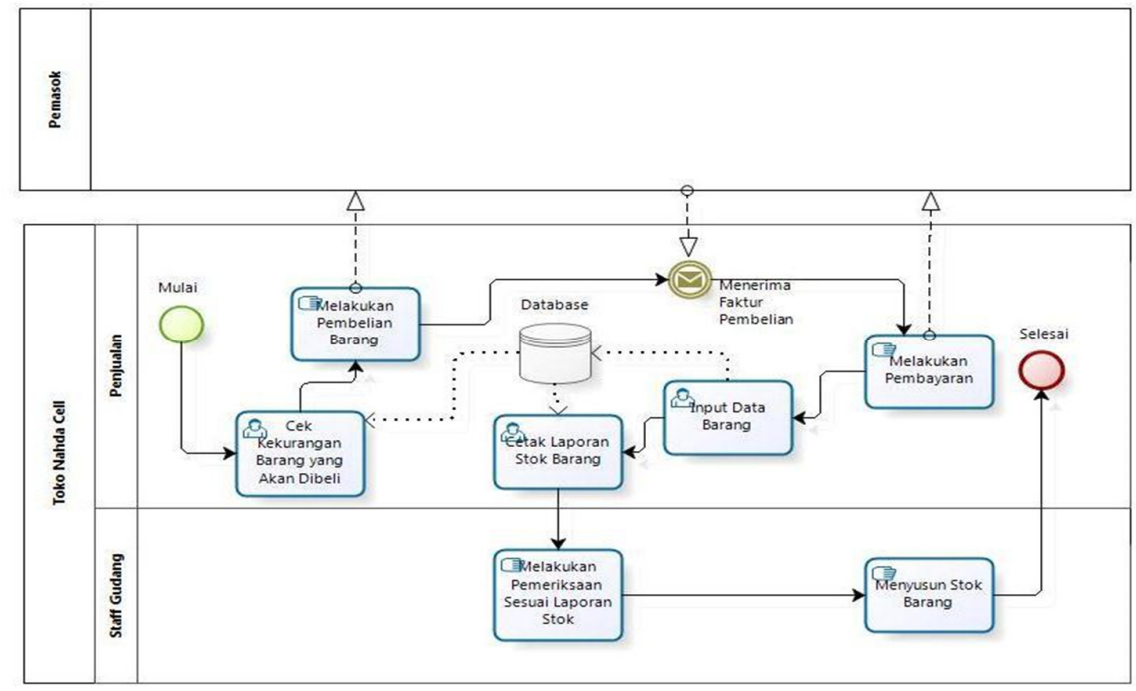

Gambar 5 Proses Inventori Handphone dan aksesoriesnya yang Diusulkan

E. Use Case Diagram

Use case diagram system penjualan dan inventory yang diusulkan pada Toko Nahda Cell, dapat dilihat pada gambar 6. Dapat kita lihat terdapat 4 aktor yang melakukan interaksi dengan system yaitu Pimpinan, Staf Gudang, Staf Penjualan dan Pelanggan. Sementara terdapat 9 case yang dilakukan oleh 4 aktor tadi yaitu cek laporan, simpan barang ke gudang, cek keluar masuk barang, cek persediaan barang, memesan barang, menerima barang, melakukan pembayaran, menerima pesanan dan menerima pembayaran.

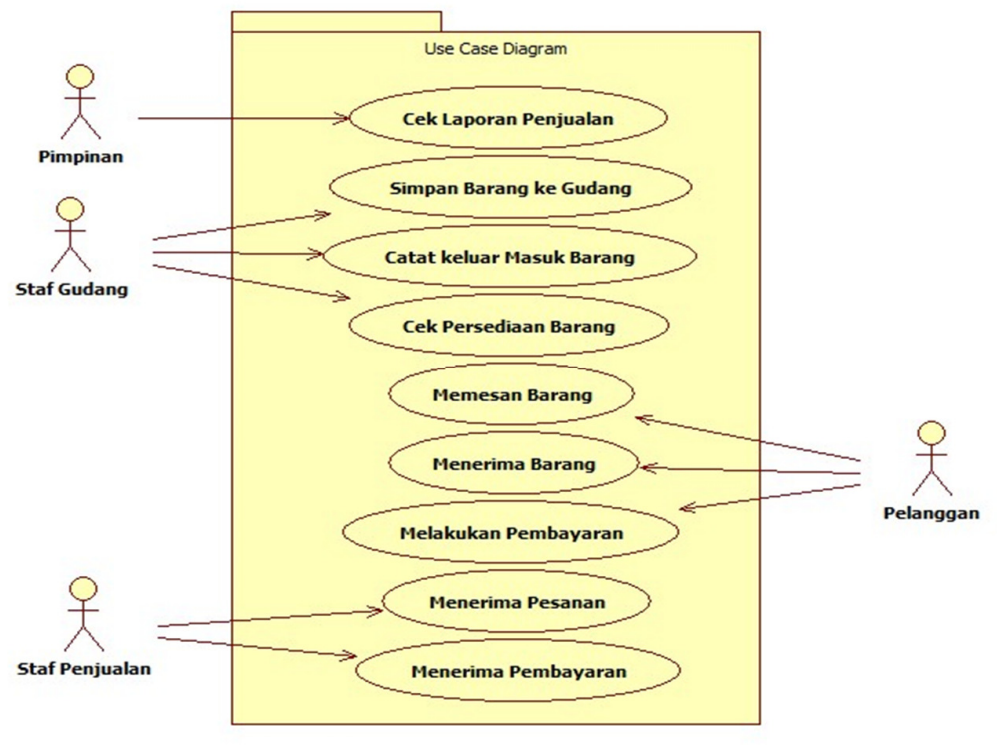

Gambar 6 Use case Diagram

\section{ANALISIS PEMILIHAN PERANGKAT LUNAK ERP}

\section{A. Perbandingan Perangkat Lunak}

Perbandingan perangkat lunak ERP mengacu dari pengembangan modul pembelajaran berdasarkan penelitian dari Andre Nofriandi dan Juliastrioza [10] yang didasari oleh penelitian sebelumnya yang dilakukan Putu Wuri Handayani dan Ultary Hariyaty pada tahun 2011 [11] . Perangkat lunak Open Source Software (OSS) ERP yang dibandingkan adalah Compiere, Openbravo, dan xTuple. Sementara itu, pada penelitian ini perangkat lunak OSS ERP yang dibandingkan adalah Openbravo, Odoo, dan WebERP. Untuk perbandingan perangkat lunak ini dilihat dari pemetaan fungsional penjualan dan distribusi barang serta pemetaan pengadaan barang yang akan menjadi stok di gudang. Kedua pemetaan fungsional ini dapat dilihat pada tabel 1 dan tabel 2. 
Tabel 1. Pemetaan Fungsional untuk Penjualan dan distribusi barang.

\begin{tabular}{|l|c|c|c|}
\hline \multicolumn{1}{|c|}{ Fitur } & Openbravo & WebERP & Odoo \\
\hline Pre Sales Activity & 17 & 22 & 13 \\
\hline Sales Order Processing & 7 & 7 & 6 \\
\hline Manage Inventory & 2 & 2 & 2 \\
\hline Manage Invoice & 5 & 5 & 5 \\
\hline Customer Payment & 3 & 3 & 3 \\
\hline Total & 34 & 39 & 29 \\
\hline
\end{tabular}

TABel 2. PemetaAn Fungsional untuk PengadaAn BARANG

\begin{tabular}{|c|c|c|c|}
\hline Fitur & Openbravo & Odoo & WebERP \\
\hline Purchase Requisition & 12 & 12 & 12 \\
\hline Maintain Quotation from Vendors & 0 & 3 & 3 \\
\hline Purchase Order & 8 & 6 & 8 \\
\hline Invoice Receipt & 6 & 6 & 6 \\
\hline Payment to Vendor & 3 & 3 & 3 \\
\hline Total & 29 & 30 & 32 \\
\hline
\end{tabular}

B. Analisa Pemilihan Perangkat Lunak ERP

Setelah melakukan beberapa perbandingan dalam pemilihan ERP open source, maka penulis memilih perangkat lunak WebERP untuk dijadikan sebagai aplikasi yang diimplementasinya dalam sistem informasi penjualan dan inventori handphone dan aksesoriesnya pada Toko Nahda Cell.

A. Spesifikasi Perangkat Keras

\section{IMPLEMENTASI DAN PENGUJIAN}

Spesifikasi komputer yang digunakan dalam penerapan aplikasi WebERP sebagai berikut:

- Komputer : : Laptop Acer Aspire 4752

- Processor : : Intel(R) core(TM) i3-2330M CPU @ $2.20 \mathrm{GHz}$

- RAM : $2 \mathrm{~GB}$

- Harddisk : $500 \mathrm{~GB}$

- Modem/LAN : Telkomsel Flash

B. Spesifikasi Perangkat lunak

Spesifikasi perangkat lunak yang digunakan untuk implementasi aplikasi WebERP sebagai berikut:

- Sistem operasi : Windows 7 Ultimate 32-bit

- Database : MySQL

- Web browser : Mozilla Firerox / Google Chrome

- Web Server : XAMPP

- Versi ERP : WebERP 4.12

\section{Instalasi WebERP}

Sebelum melakukan instalasi WebERP, lakukan instalasi XAMPP terlebih dahulu. Setelah melakukan instalasi XAMPP, selanjutnya dilakukan instalasi ERP WebERP. Aplikasi WebERP bisa di download melalui website resmi WebERP yaitu www.weberp.org. dalam penelitian ini, versi yang digunakan untuk penerapan adalah webERP 4.12.3. Gambar 7 merupakan tampilan awal setelah dilakukan instalasi WebERP. Setelah dilakukan instalasi ini, langkah selanjutnya adalah membuat database, melakukan settingan terhadap berbagai modul aplikasi yang dibutuhkan dan penginputan data master. 


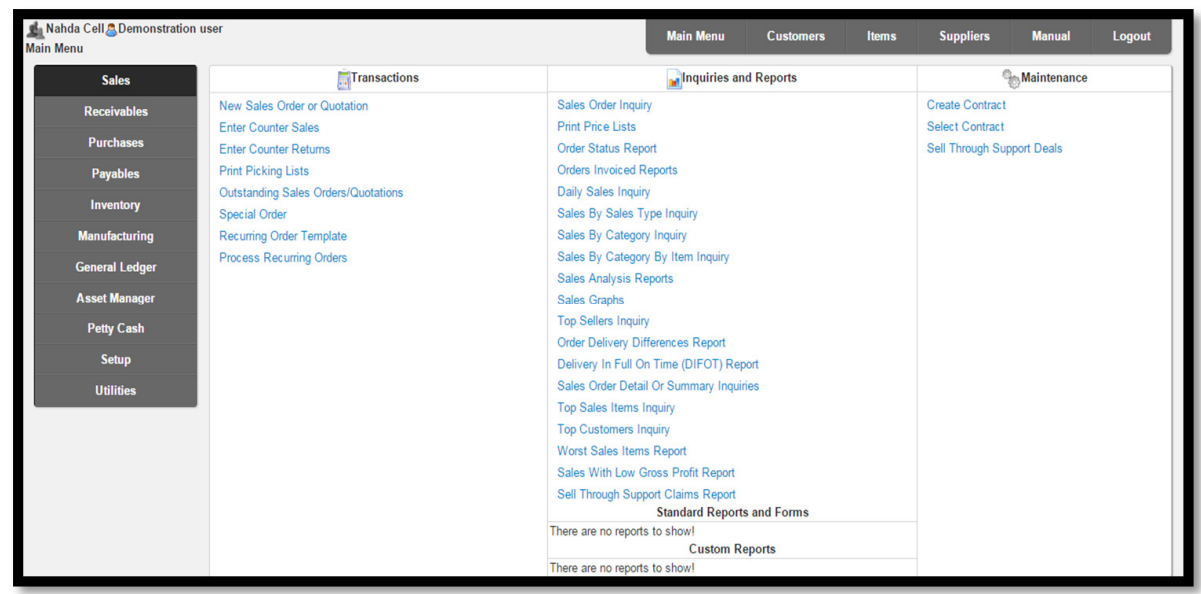

Gambar 7 Tampilan Utama WebERP

D. Persiapan Penerapan Aplikasi

Setelah proses persiapan instalasi perangkat yang dibutuhkan selesai, tahap selanjutnya adalah melakukan penerapan aplikasi. Pada Toko Nahda Cell, ada beberapa pengaturan awal yang harus dilakukan yaitu:

a. Membuat Database

b. Input data Pemasok

c. Input data Costumer

d. Input Data Barang

e. Pengaturan Gudang.

E. Implementasi Aplikasi WebERP

Dalam tahap implementasi merupakan tahap penyesuaian proses bisnis dengan aplikasi yang digunakan. Tahapannya yaitu: persediaan barang dan penjualan barang.

1) Penjualan Barang Dagang

Langkah-langkah penjualan barang kepada pelanggan dengan menggunakan aplikasi WebERP adalah sebagai berikut:

a. Pemesanan Barang Oleh Pelanggan

Pada tahap ini pelanggan dapat memesan barang yang diinginkannya, bisa dengan memperlihatkan list barang yang akan dibeli atau langsung meminta kepada Staf Penjualan. Setelah itu data pelanggan dan barang yang dibeli diinputkan dalam aplikasi dan data tersimpan dalam database. Dari barang yang sudah dibeli tadi akan terjadi pengurangan stok nantinya di sistem. Pengurangan stok ini tentunya akan dilakukan pengecekan secara fisik di gudang. Interface dari form input pemesanan barang oleh pelanggan dapat dilihat pada gambar 8 . 


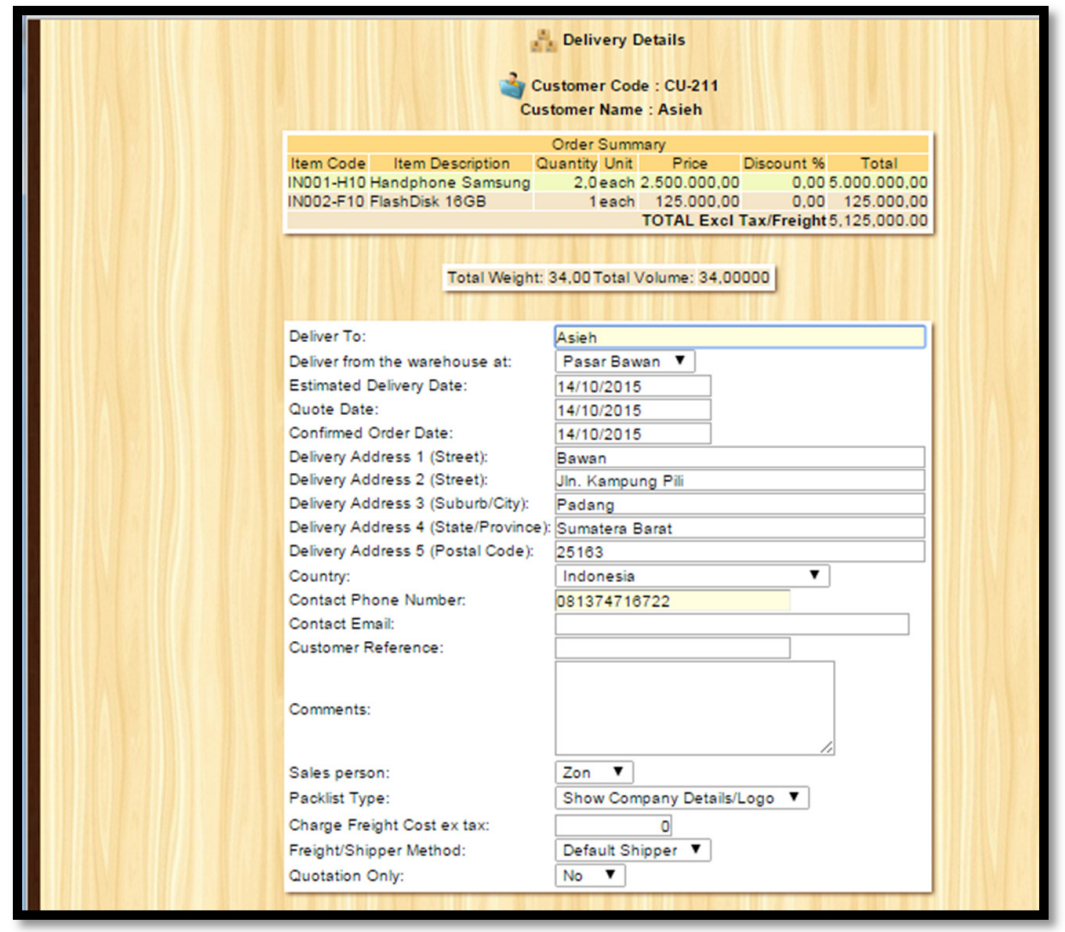

Gambar 8 Tampilan Pemesanan Barang Oleh Pelanggan

b. Pembayaran Belanjaan

Setelah pemesanan barang selesai, pelanggan akan melakukan pembayaran terhadap barang yang sudah dibelinya. Setelah melakukan pembayaran, pelanggan akan mendapatkan struk atau faktur pembelian yang akan menjadi bukti bahwa dia telah melakukan pembayaran. Sementara untuk Toko Nahda Cell, di sistemnya akan tercatat pendapatan pada hari itu, dan laporannya bisa di print out jika diperlukan. Form antar muka pembayaran pada aplikasi dan faktur yang diterima pelanggan dapat dilihat pada gambar 9 dan gambar 10

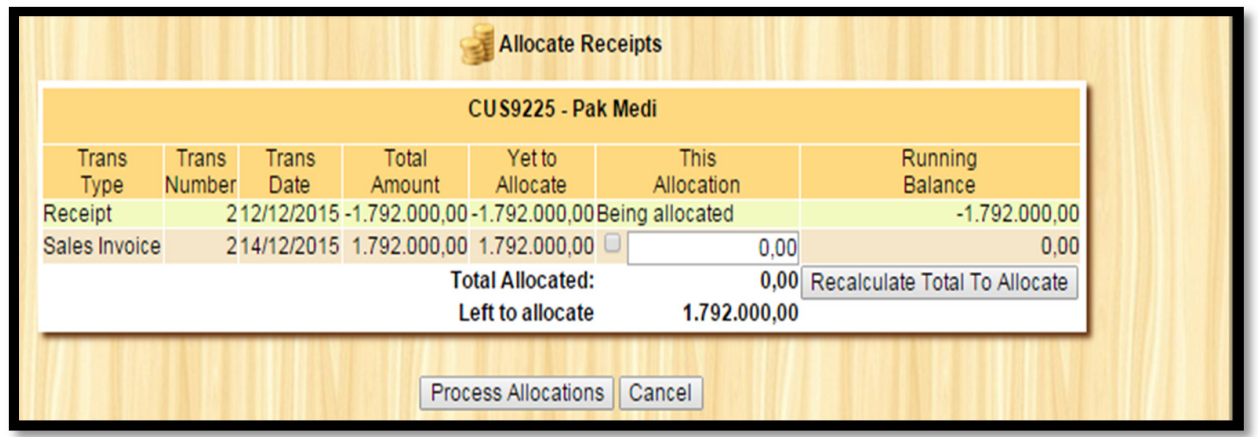

Gambar 9 Tampilan Penerimaan Pembayaran dari Pelanggan 


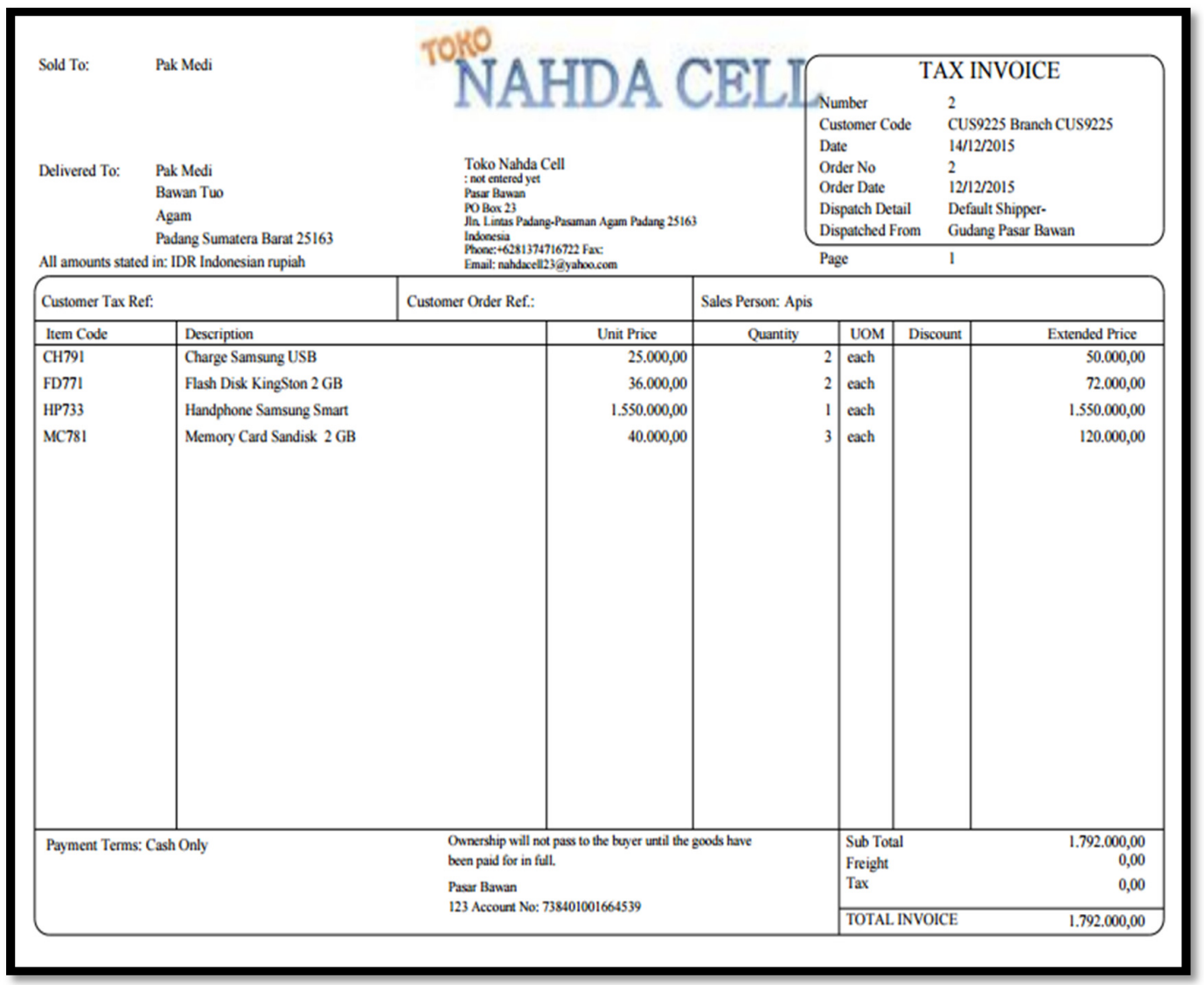

Gambar 10 Tampilan Faktur Pembayran yang diterima oleh Pelanggan

2) Pengaturan Inventori dan Barang Dagang

Pada pengaturan inventory ini berguna untuk memastikan data barang dagang yang tersedia didalam gudang. Sebelum memasukan data, maka langkah awal dalam pengaturan inventory ini adalah dengan membuat lokasi gudang yang dimiliki. Pada Toko Nahda Cell ini lokasi gudangnya terletak di Toko Nahda Cell itu sendiri. Pembuatan lokasi gudang dapat dilihat pada gambar 11.

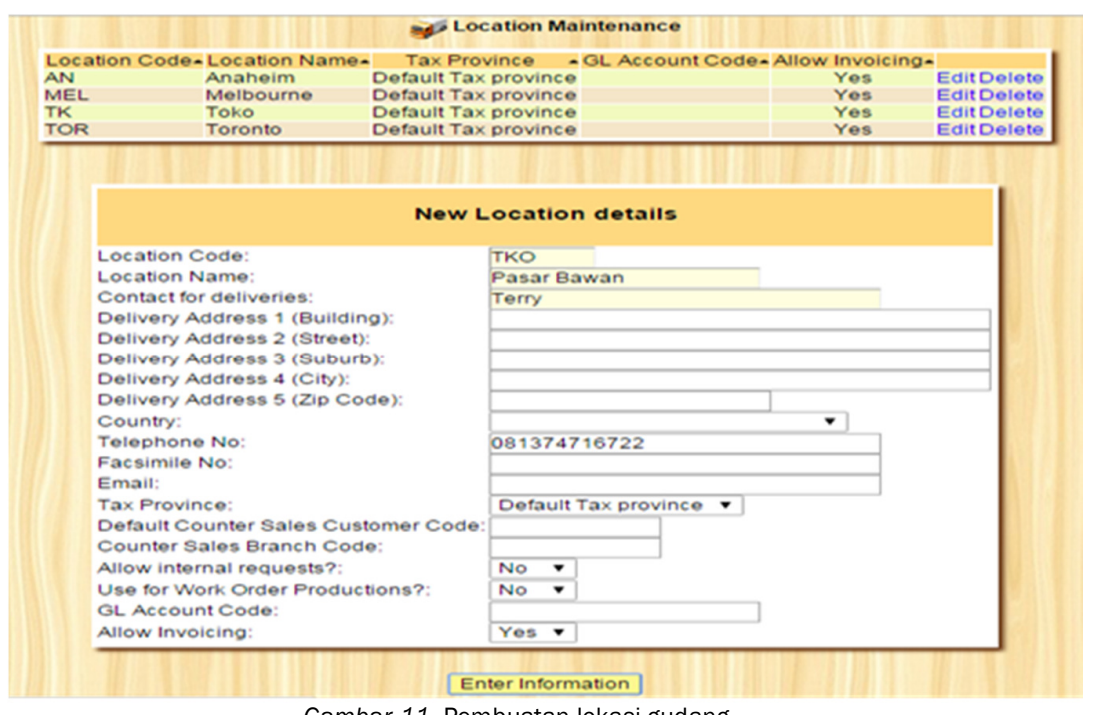

Gambar 11 Pembuatan lokasi gudang

Setelah pembuatan lokasi gudang selesai, maka langkah selanjutnya adalah pembuatan kategori stok. Hal ini bertujuan untuk mengelompokan persediaan barang yang ada seperti handpnone, 
flashdisk, charge, baterai, dan lain-lain. Proses pembuatan kategori stok dapat dilihat pada gambar 12.

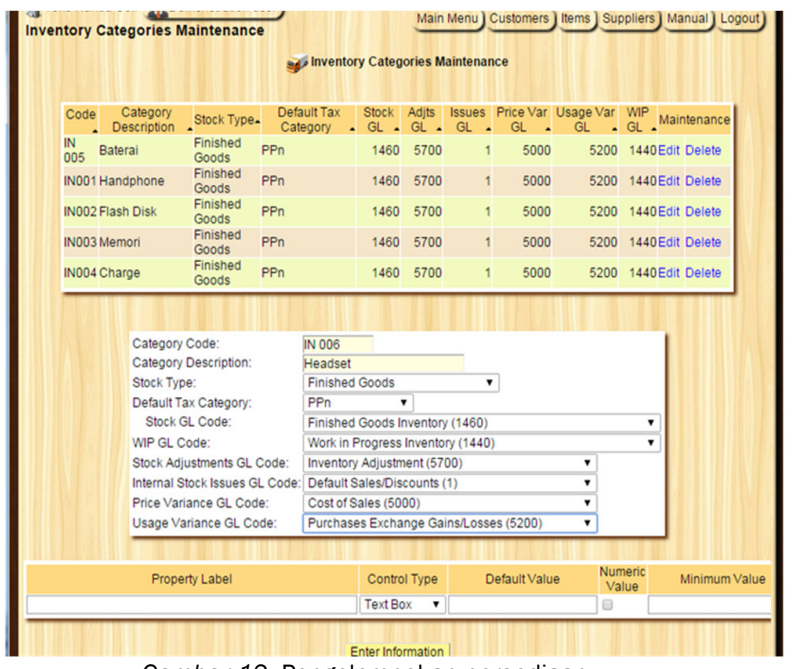

Gambar 12 Pengelompokan persediaan

\section{F. Pengujian}

Pada Tahap ini hasil dari penerapan aplikasi telah dapat dilihat. Selain itu hasil dari laporan penjualan pun dapat dibandingkan dengan laporan manual yang ada sebelumnya di Toko Nahda Cell.

a. Pengujian Laporan Penjualan

Pencatatan laporan penjualan pada Toko Nahda Cell dilakukan dengan proses manual. Hal ini tentu akan rentan terjadi salah dalam pencatatan. Bentuk dari laporan manual pencatatan penjualan dapat dilihat pada gambar 13 .

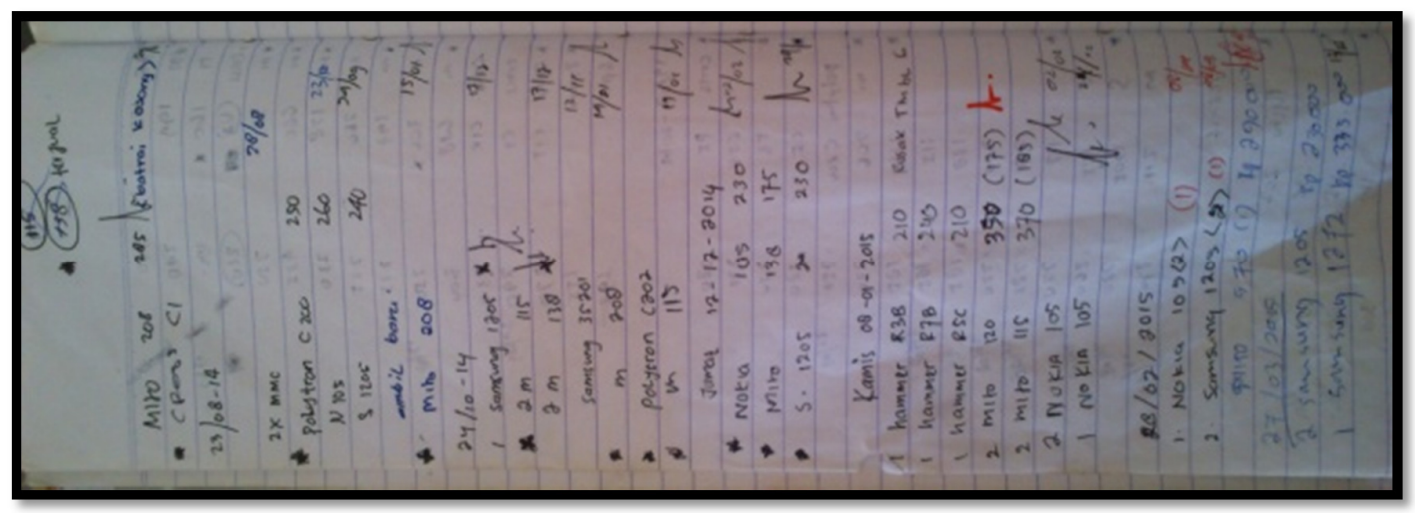

Gambar 13 List Laporan Penjualan Manual

Sedangkan laporan penjualan yang dihasilkan oleh aplikasi WebERP dapat dilihat pada gambar 14. 


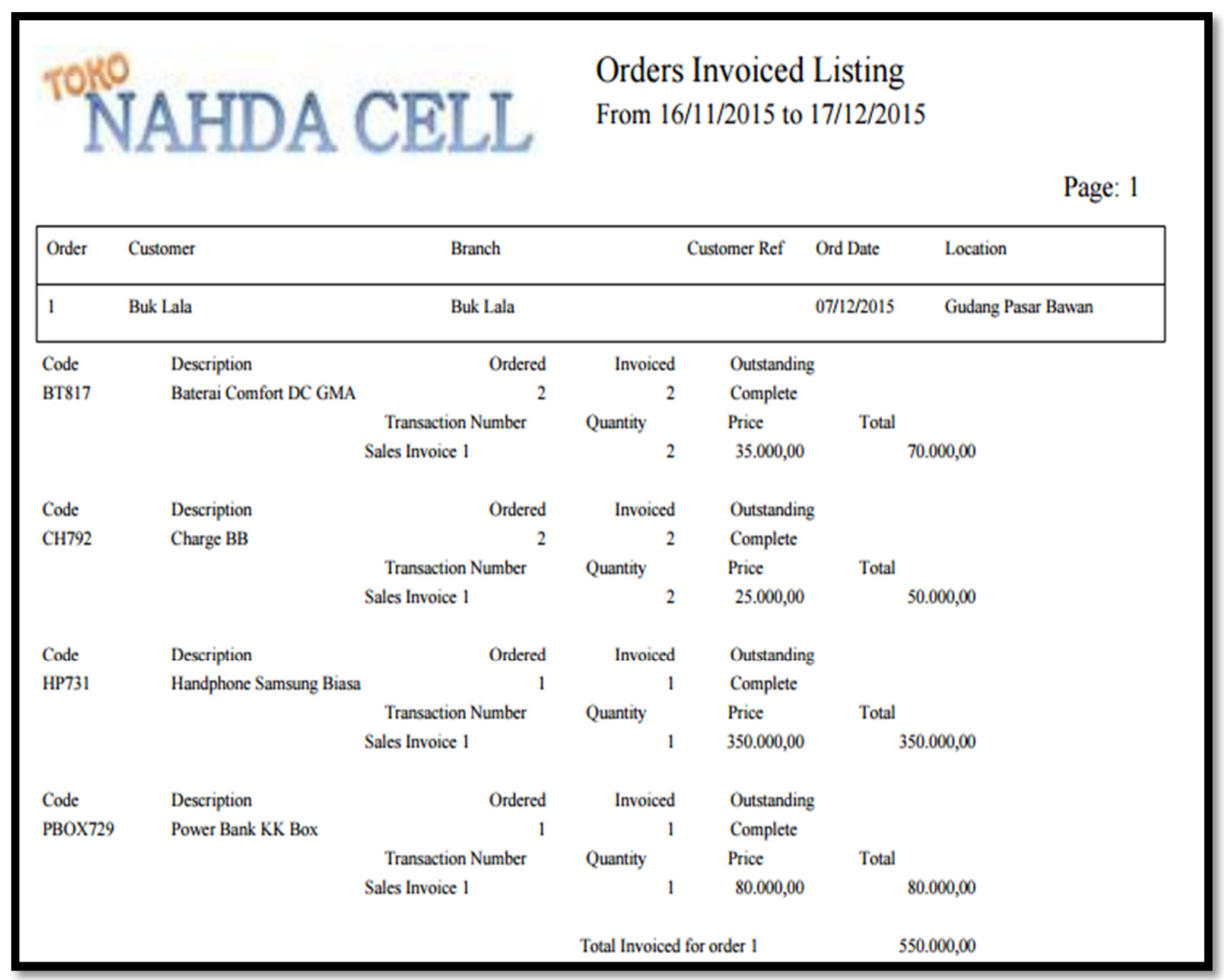

Gambar 14 List Laporan Penjualan

Berdasarkan pengujian tersebut, dapat disimpulkan bahwa aplikasi WebERP dapat menghasilkan laporang yang lebih baik dan sesuai dengan laporan yang dibuat secara manual.

b. Laporan Yang Dihasilkan

Laporan yang dihasilkan dari proses bisnis ini di Toko Nahda Cell adalah laporan penjualan, Iaporan valuasi inventory, laporan perencanaan inventory, dan laporan Stok Inventory.

c. Pengujian Fungsional Sistem

Pengujian dilakukan dengan memberikan form User Acceptance Test (UAT) kepada user (Pimpinan, Staff Penjualan, dan staff gudang) yang akan memakai sistem. Berdasarkan hasil form UAT dapat disimpulkan bahwa fungsional aplikasi WebERP telah sesuai dengan kebutuhan sistem yang diharapkan. Bentuk Form UAT yang diisi oleh user setelah mencoba aplikasi WebERP ini dapat dilihat pada gambar 15.

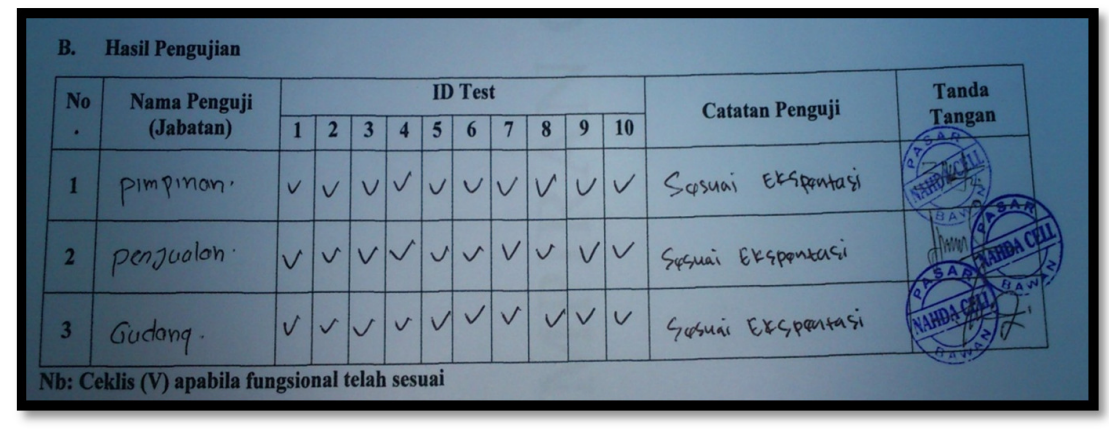

Gambar 15. Form UAT yang diisi oleh User setelah Mencoba Aplikasi WebERP 
G. Indikator Keberhasilan

Dari tabel 3 dapat disimpulkan bahwa penerapan aplikasi WebERP lebih cepat dan efisien pada sebagian besar proses bisnis yang terjadi pada Toko Nahda Cell jika dibandingkan dengan sebelum menerapkan aplikasi WebERP. Hal ini dapat terlihat dari durasi waktu yang dibutuhkan saat pengerjaan proses bisnis masing-masingnya.

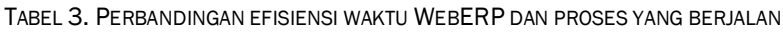

\begin{tabular}{|l|l|l|l|}
\hline No & \multicolumn{1}{|c|}{ Indikator perbandingan } & $\begin{array}{c}\text { Tanpa aplikasi } \\
\text { WebERP }\end{array}$ & \multicolumn{1}{|c|}{$\begin{array}{c}\text { Dengan aplikasi } \\
\text { WebERP }\end{array}$} \\
\hline 1 & Membuat faktur penjualan & 3 menit & 1 menit \\
\hline 2 & Pembuatan laporan penjualan & 15 menit & 1 menit \\
\hline 3 & Penghitungan stok barang & 20 menit & 1 menit \\
\hline 4 & Penghitungan stok barang & 7 menit & 1 menit \\
\hline 5 & $\begin{array}{l}\text { Mencatat/memasukkan data } \\
\text { barang }\end{array}$ & 10 menit & 15 menit \\
\hline
\end{tabular}

VI. PENUTUP

a. Kesimpulan

Dari penerapan aplikasi yang dilakukan mulai dari tahapan identifikasi masalah, analisis, penerapan dan pengujian aplikasi WebERP pada Toko Nahda Cell dapat diambil kesimpulan yaitu Enterprise Resource Planning (ERP) pada sistem penjualan dan inventory barang dengan aplikasi WebERP telah berhasil diterapkan dengan rincian sebagai berikut:

a. Proses bisnis penjualan handphone dengan aksesorisnya yang ada Toko Nahda Cell belum menggunakan sistem yang dikelola secara terkomputerisasi. Selain itu laporan tentang persediaan barang juga tidak diketahui. Untuk dapat membantu dalam proses bisnis penjualan dan inventory, maka diberikanlah usulan untuk menerapkankan solusi terintegrasi dalam bentuk penerapan sistem ERP. Proses bisnis penjualan digambarkan dengan Bussiness Process Model Notation.

b. Sistem terkomputerisasi yang diusulkan pada penerapan aplikasi ERP di Toko Nahda Cell ini menggunakan aplikasi WebERP. Untuk Menerapkan aplikasi WebERP ini, perlu dilakukan beberapa pengaturan supaya dapat difungsikan dengan sesuai kebutuhan Toko Nahda Cell. Setelah diterapkan maka dilakukan pengujian aplikasi untuk membuktikan bahwa proses bisnis yang terjadi di Toko Nahda Cell telah dapat berjalan lebih baik lagi dari sebelumnya.

c. Pengujian aplikasi WebERP membuktikan bahwa pembuatan laporan dapat dilakukan dengan lebih cepat dan lebih akurat. Laporan yang dihasilkan dari proses bisnis di Toko Nahda Cell berupa laporan penjualan, laporan valuasi inventory, laporan perencanaan inventory, dan laporan Stok Inventory.

b. Saran

Berdasarkan kesimpulan diatas, maka disarankan kepada peneliti selanjutnya untuk melakukan pengembangan implementasi WebERP bukan hanya pada sistem penjualan dan inventory saja tetapi juga untuk pengelolaan customer relationship management, modul Human Resource manajement dan ecommerce.

\section{REFERENSI}

[1] https://www.academia.edu/4941258/ Diakses tanggal 13 Oktober 2015

[2] Arbie, E. 2000. Pengantar Sistem Informasi Manajemen. Bina Alumni Indonesia. Jakarta, 7(1). Astuti, Karina Dewi. 2012. Perancangan Aplikasi Penjualan di UKM

[3] Tafri D. Muhyuzir. 2001. Analisa Perancangan Sistem Pengolahan Data. Jakarta: 170 PT. Elex Media Komputindo

[4] Dhewanto, W. dan Falahah. 2007. ERP (enterprise resource planning) menyeleraskan teknologi informasi dengan strategi bisnis. Bandung : Informatika

[5] Islamiyah S.N. 2010. Analisis dan Implementasi Modul Voucher Financial Management pada OpenErp. Jakarta : Universitas Gunadarma

[6] Motiwalla, Luvai. V dan Jeff Thompson. (2009). Enterprise Systems for Management. Pearson Education, Inc, New Jersey, USA

[7] Mulyadi. 2008, Sistem Akuntansi. Jakarta : Salemba Empat 
[8] Ikatan Akuntansi Indonesia. 2009. Standar Akuntansi Keuangan. Jakarta : Ikatan Akuntansi Indonesia

[9] Sipper, D and R. L. Buffin. 1997. Production: Planning, Control and Integration. Mc Graw Hill. Singapore

[10] Juliastrioza. 2015. Penerapan Enterprise Resource Planning (ERP) Untuk Sistem Informasi Pembelian, Persediaan, Dan Penjualan Barang Menggunakan Aplikasi Odoo Pada Toko Emi Grosir Dan Eceran. Padang: Universitas Andalas.

[11] Handayani, Putu Wuri. Ultary Hariyaty. 2011. Analisis Fungsionalitas Open Source Software ERP Untuk Pengembangan Modul Pembelajaran ERP. Jawa Barat: Universitas Indonesia. Jurnal Sistem Informasi, 7(2)

O(3). ISSN : 0854-9524.

[12] Isnaeni L.A. 2010. Perancangan Sistem Enterprise Resource Planning (ERP) menggunakan Openbravo Modul Sales Management Sub Modul Sales Order Pada PT.ABC .Jakarta :Universitas Gunadarma 